\title{
Anti-inflammatory, analgesic, and immunostimulatory effects of Luehea divaricata Mart. \& Zucc. (Malvaceae) bark
}

\author{
Roseane Leandra da Rosa ${ }^{1}$, Geisson Marcos Nardi', Adriana Graziele de Farias Januário', Renata \\ Boçois $^{1}$, Katiane Paula Bagatini ${ }^{1}$, Sandro José Ribeiro Bonatto ${ }^{2}$, Andrea de Oliveira Pinto ${ }^{1}$, João \\ Ronaldo Notargiacomo Ferreira ${ }^{3}$, Luisa Nathália Bolda Mariano ${ }^{4}$, Rivaldo Niero ${ }^{4}$, Fabíola Iagher ${ }^{5 *}$
}

\author{
${ }^{1}$ Area of Biological and Health Sciences, West University of Santa Catarina, Joaçaba, SC, Brazil, ${ }^{2}$ Pelé Pequeno Príncipe \\ Research Institute, Curitiba, PR, Brazil, ${ }^{3}$ Area of Biological and Health Sciences, Pharmacy Graduation, West University of \\ Santa Catarina, Videira, SC, Brazil, ${ }^{4}$ Chemical-Pharmaceutical Research Center University, Vale do Itajai University, Itajai, \\ SC, Brazil, ${ }^{5}$ Cell Metabolism Laboratory, Department of Physiology, Biological Science Building, Federal University of
} Parana, Curitiba, PR, Brazil

\begin{abstract}
Luehea divaricata (Malvaceae) is a plant widely used for treatment of various inflammatory and infectious conditions; however few reports discuss its biological properties. The aim of this study was to evaluate the anti-inflammatory and analgesic effects as well as the macrophage activity in mice treated with the hydroalcoholic crude extract of $L$. divaricata (CLD). Thin layer chromatography revealed presence of epicathequin, stigmasterol, lupeol and $\alpha, \beta$-amyrin in the extract. To evaluate the anti-inflammatory and analgesic activities, animals were subjected to paw edema induced by carrageenan test, writhing, formalin and capsaicin tests. Immunomodulatory activity was evaluated by adhesion and phagocytic capacity, lysosomal volume, and reactive oxygen species (ROS) production by peritoneal macrophages, after daily treatment with CLD for 15 days. CLD promoted reduction in paw edema ( $36.8 \%$ and $50.2 \%$; $<<0.05$ at doses of 100 and $300 \mathrm{mg} / \mathrm{kg}$, respectively), inhibited writhing behavior at the higher dose (64.4\%, $\mathrm{p}<0.05)$, reduced formalin reactivity $(81.2 \%$ and $91.6 \%$ at doses of 100 and $300 \mathrm{mg} / \mathrm{kg}$, respectively, $\mathrm{p}<0.05)$, and reduced capsaicin reactivity by $63.9 \%(300 \mathrm{mg} / \mathrm{kg})$. CLD $\left(200 \mathrm{mg} \cdot \mathrm{kg}^{-1} \cdot \mathrm{day}^{-1}\right)$ increased phagocytosis capacity of macrophages ( $\sim 3$ fold, $\mathrm{p}<0.05)$, neutral red uptake $(\sim 50 \%, \mathrm{p}<0.001)$, and ROS production $(\sim 90 \%, \mathrm{p}<0.001)$. These data suggest that CLD possesses anti-inflammatory, analgesic and immunostimulatory properties.
\end{abstract}

Uniterms: Luehea divaricata Mart. \& Zucc./pharmacognosy. Luehea divaricata Mart. \& Zucc./ hydroalcoholic crude extract/properties. Anti-inflammatories. Analgesics. Reactive oxygen species.

Luehea divaricata (Malvaceae) é utilizada para o tratamento de várias condições patológicas, entretanto, há poucos relatos sobre sua bioatividade. O objetivo deste estudo foi avaliar o efeito anti-inflamatório e analgésico, bem como a atividade de macrófagos em camundongos tratados com extrato bruto hidroalcoólico (CLD) da planta. Cromatografia em camada delgada revelou a presença de epicatequina, estigmasterol, lupeol e $\alpha, \beta$-amirina no material. Para avaliar a atividade anti-inflamatória e analgésica, animais foram submetidos a teste de edema de pata induzido por carragenana, teste de contorções, da formalina e da capsaicina. A atividade imunomodulatória foi avaliada pela capacidade de adesão e de fagocitose dos macrófagos, volume lisossômico e produção de espécies reativas de oxigênio (ROS), após tratamento diário com CLD por 15 dias. CLD promoveu redução do edema de pata $(36,8 \%$ e $50,2 \%$; 100 e $300 \mathrm{mg} / \mathrm{kg}$, respectivamente; $\mathrm{p}<0,05)$, redução do número de contorções $(64,4 \% ; 300 \mathrm{mg} / \mathrm{kg}$; $\mathrm{p}<0,05)$, redução da reatividade no teste da formalina $(81,2 \%$ e $91,6 \% ; 100$ e $300 \mathrm{mg} / \mathrm{kg}$, respectivamente; $\mathrm{p}<0,05)$, e no teste da capsaicina em $63,9 \%(300 \mathrm{mg} / \mathrm{kg})$. CLD $\left(200 \mathrm{mg} \cdot \mathrm{kg}^{-1} \cdot \mathrm{day}^{-1}\right)$ aumentou capacidade

*Correspondence: F. Iagher. Universidade Federal do Paraná. Av. Coronel Francisco H. dos Santos, s/n, 81530-900 - Curitiba - PR, Brasil. E-mail: fabiola.iagher@ufpr.br 
de fagocitose dos macrófagos ( $\sim 3$ vezes, $\mathrm{p}<0,05)$, volume lisossômico $(\sim 50 \%, \mathrm{p}<0,001)$ e produção de $\operatorname{ROS}(\sim 90 \%, \mathrm{p}<0,001)$. Estes dados sugerem que o CLD possui propriedades anti-inflamatórias, analgésicas e imunoestimulatórias.

Unitermos: Luehea divaricata Mart. \& Zucc./farmacognosia. Luehea divaricata Mart. \& Zucc./extrato bruto hidroalcoólico/propriedades. Antiinflamatórios. Analgésicos. Espécies reativas de oxigênio.

\section{INTRODUCTION}

Luehea divaricata Mart. \& Zucc. (Malvaceae) is a plant found in the South Region of Brazil and popularly known as "açoita-cavalo" by the local inhabitants. Its barks have been empirically described by local herbalists in Santa Catarina - Brazil to possess antimicrobial and anti-inflammatory properties, and it has been used in the treatment of respiratory and gastrointestinal infections, arthritis, rheumatism, and leukorrhea, and as vermifuge (data not published).

Despite the consumption of bark infusions by the local population, there is little scientific information about its biological activities. Antifungal properties have been attributed to a dichloromethane extract of L. divaricata barks ( $25 \mu \mathrm{g} /$ filter disk), which was able to inhibit polymer synthesis or the assembly of the cell wall of Neurospora crassa (Zacchino et al., 1998). In 2003, Brazilian research characterized two triterpenes (a tormentic acid derivative and maslinic acid), which were obtained from a methanolic extract of $L$. divaricata leaves (Tanaka, Vidotti, Silva, 2003), but the biological properties of these compounds have not been assessed. The same research group identified a flavonoid, epicatechin, from a methanolic extract of the leaves of $L$. divaricata, which demonstrated antimicrobial activity against Staphylococcus aureus $(250-500 \mu \mathrm{g} / \mathrm{mL})$ (Tanaka et al., 2005). Coelho de Souza et al. (2004) also verified the antimicrobial activity of a methanolic extract $(50 \mathrm{mg} / \mathrm{mL})$ of the aerial parts of $L$. divaricata. Although previous research suggests that $L$. divaricata possesses biological activity, no known studies have validated the effectiveness of $L$. divaricata in the control of inflammatory diseases and pain or investigated the immunomodulatory capacity of this plant.

Inflammation is a complex process involving a network of chemical signals that mediate the actions of the immune system. During inflammation, serum proteins and leukocytes migrate to areas of tissue injury. These inflammatory and activated cells release vasoactive mediators such as nitric oxide, bradykinin, and metabolites of arachidonic acid, all of which increase regional blood flow and promote microvascular permeability (Suffredini et al., 1999). Several inflammatory mediators, mainly bradykinin and metabolites of arachidonic acid, are potent pain-producing agents that can excite and sensitize nociceptive primary afferent neurons (Petho, Reeh, 2012). Several plant extracts have been studied for their anti-inflammatory properties, by using in vitro and in vivo models (Ojewole, 2006; Siriwatanametanon et al., 2010; Areej et al., 2013), and existing data suggest that $L$. divaricata may also have similar characteristics.

Apart from anti-inflammatory qualities, natural compounds exhibit properties that may interfere with the modulation mechanisms of innate immunity, more specifically, the function of macrophages (Napolitano et al., 2005; Lee et al., 2007; Cruz et al., 2007). Plant derivatives present an exciting opportunity for the discovery of new therapeutic agents and adjuvants that exhibit immunomodulatory properties, potentially representing suitable alternatives for the prevention and treatment of immune-related pathologies (Kalluf, 2008; Tiwari et al., 2004). Plant extracts capable of stimulating the immune system might be useful in the treatment and prevention of infections. Immunostimulatory effects of plant-derived medicines following oral administration could be relevant in the search of new-generation vaccine adjuvants (Licciardi, Underwood, 2011). On the other hand, compounds that exert immunosuppression would be desirable in the treatment of autoimmune and chronic inflammatory diseases. Studies involving macrophages are very significant since they constitute the first line of defense of an organism and are responsible for activating many other processes involved in immune defense. In relation to macrophage functions, plant extracts have been shown to reduce nitric oxide production (Mehrotra et al., 2002; Napolitano et al., 2005), and reduce phagocytosis and expression of plasma membrane proteins (Lee et $a l ., 2007)$, as well as stimulate phagocytic capacity and production of nitric oxide (Cruz et al., 2007).

To understand the biological potential of $L$. divaricata, the present study aimed to investigate the anti-inflammatory, analgesic, and immunomodulatory effects of the hydroalcoholic crude extract of L. divaricata (CLD) bark in mice. These data are an important starting point to characterize the potential biological benefits of 
L. divaricata and define some of its practical therapeutic applications in drug development.

\section{MATERIAL AND METHODS}

\section{Animal care}

Adult female Swiss mice weighing 25-35 g were supplied by the West University of Santa Catarina. The animals were maintained in a controlled environment at $22^{\circ} \mathrm{C} \pm 2{ }^{\circ} \mathrm{C}$ with a $12 \mathrm{~h}$ light/dark cycle, with free access to water and food. All animals were acclimatized to the test laboratory $24 \mathrm{~h}$ prior to experiments. All procedures were approved by the Institutional Ethics Committee of West University of Santa Catarina (documents numbers: 011/2004, 135/2005 and 001/2010) and are in accordance with NIH Animal Care Guidelines.

\section{Drugs and reagents}

Carrageenan type IV, capsaicin, zymosan, nitroblue tetrazolium (NBT), horseradish peroxidase, neutral red, phenol red, phorbol myristate acetate (PMA), acetic acid, formaldehyde and dimethylsulfoxide (DMSO) were all purchased from Sigma-Aldrich (St. Louis, MO, USA).

\section{Plant material and preparation of crude extract}

The barks of L. divaricata were collected in March 2000, in Santa Clara, Joaçaba, Santa Catarina, Brazil (geographic coordinates: $27.1758^{\circ} \mathrm{S}, 51.5662^{\circ} \mathrm{W}$ ). The specimen was identified with the collection documenting number 382.136 at the Municipal Botanical Museum, Curitiba-PR, Brazil, and stored at the same local. The collected barks of $L$. divaricata was then dried under ventilation in an air-flow chamber and pulverized. The powder was submitted to extraction by maceration (25$30^{\circ} \mathrm{C}$ ), with ethanol $80^{\circ} \mathrm{GL}$ for 14 days. The extract was filtered and concentrated in a vacuum with a rotatory evaporator, until completely dry. The dried extract was then stored at $-20^{\circ} \mathrm{C}$ until use.

\section{Phytochemical analysis}

$1 \mathrm{~g}$ of crude extract of $L$. divaricata was dissolved in $5 \mathrm{~mL}$ of ethyl acetate or chloroform. After $5 \mathrm{~min}$, the solution was filtered and dried to obtain ethyl acetate (SAE) or chloroform $\left(\mathrm{SCHCl}_{3}\right)$ samples. The yield of $\mathrm{SAE}$ and $\mathrm{SCHCl}_{3}$ was $2.96 \%$ and $6.29 \%$, respectively. Both fractions were checked by thin layer chromatography (TLC) according Hostettmann, Marston and Hostettmann
(1998). In order to perform TLC, different eluents and systems as mobile phase were used, and silica gel $60 \mathrm{~F}_{254}$ (Merck) as stationary phase. It was used standards from the bank's laboratory, stigmasterol, lupeol, $\alpha, \beta$-amyrin, vitexin, rutin, quercetin and epicatechin. Some of these compounds were isolated from the plant under study.

The chromatographic $\mathrm{SCHCl}_{3}$ profile was carried out with two different solvent systems, hexane:acetone 7:3 and $8: 2$, and the standards used were $\alpha, \beta$-amyrin, lupeol and stigmasterol. The SAE profile was performed with chloroform: methanol 8:2, using vitexin, rutin, epicatechin and quercetin as standards. In both cases, the spots were revealed using sulfuric anisaldehyde to $110^{\circ} \mathrm{C}$ and ferric chloride.

\section{Paw edema induced by carrageenan test}

Experimental animals $(n=6-10)$ were pre-treated with the crude extract of $L$. divaricata (CLD) at doses of $10-300 \mathrm{mg} / \mathrm{kg}$, orally administered (via oral, v.o.), and control animals $(\mathrm{n}=10)$ received a vehicle (distilled water; $0.1 \mathrm{~mL} / 10 \mathrm{~g}$ ) in place of the CLD. After $1 \mathrm{~h}$, the mice were anesthetized with halothane and were administered carrageenan (300 $\mu \mathrm{g} / \mathrm{paw}$, subcutaneous injection) into the right paw (Morris, 2003). The contralateral paw received the same volume of sterile phosphatebuffered saline (PBS) and served as a control. The paw volume was measured with a plethysmometer (Panlab, Barcelona, Spain) immediately after carrageenan or PBS administration, at specified time points $(30,60,120$, and 240 min after injection of phlogistic agent). The results are expressed as the mean \pm standard error of mean (SEM) values of the difference in volume (in mililiters) between the carrageenan- and saline-treated paws.

\section{Writhing test}

Writhing is induced by an intraperitoneal (i.p.) injection of acetic acid $(0.6 \%)$ as an irritant, following which writhing movements are observed and evaluated for 30 min (Koster, Anderson, Debeer, 1959). Experimental animals ( $\mathrm{n}=6-10)$ were pre-treated with the CLD at doses of $10-300 \mathrm{mg} / \mathrm{kg}$, orally administered (via oral, v.o.) $1 \mathrm{~h}$ prior to injection of acetic acid. Control animals $(\mathrm{n}=10)$ received a vehicle (distilled water; $0.1 \mathrm{~mL} / 10 \mathrm{~g}$ ) in place of the CLD. The results are expressed as the mean \pm SEM of the number of times the animal writhed.

\section{Paw formalin and capsaicin tests}

Nociceptive behavior was induced by the injection 
of formalin (Hunskaar, Hole, 1987) or capsaicin (Sakurada et al., 1992) in the ventral surface of the right hind paw. Animals $(n=6-10)$ were pre-treated as specified in the above-described writhing test. After $1 \mathrm{~h}$ of pretreatment with CLD or vehicle, the animals received a $20 \mu \mathrm{L}$ injection of either $2.5 \%$ formalin solution $(0.92 \%$ formaldehyde) or capsaicin $(1.6 \mu \mathrm{g} / \mathrm{paw})$ prepared in PBS. Following formalin or capsaicin injection, the mice were immediately placed in glass chambers, and the time spent licking, flicking, and biting the injected paw was measured with a stopwatch; this time (expressed in seconds) was considered an indication of nociception. This nociceptive behavior is recorded in two phases for the formalin test and only in the one phase for the capsaicin test. The first phase of nociceptive response normally peaks at 0-5 min, and the second phase, 15-30 min after the formalin injection. The results are expressed as the mean \pm SEM of nociceptive behavior (in seconds).

\section{Immunostimulatory activity evaluation and macrophage isolation}

Animals were randomly separated into three groups, $\mathrm{n}=5$ animals/group: Control Group, animals received only a vehicle (a solution consisting of $10 \%$ DMSO and 40\% Tween 80 in saline); Treatment Group 100, received $100 \mathrm{mg} \cdot \mathrm{kg}$ body weight ${ }^{-1} \cdot$ day $^{-1}$ of CLD; Group 200, received $200 \mathrm{mg} \cdot \mathrm{kg}$ body weight ${ }^{-1} \cdot$ day $^{-1}$. Body weight was measured immediately before administration. All animals were fed a regular chow diet $\left(\right.$ Nuvital $\left.^{\mathbb{}}\right)$ and received water ad libitum, and the treatments with CLD or vehicle were performed by gavage daily for 15 days. After this period, the animals were sacrificed in a $\mathrm{CO}_{2}$ chamber, and the macrophages were collected. This experiment was performed in triplicate such that the total number of animals evaluated per group was 15 .

Following euthanasia, the resident macrophages were obtained after i.p. injection of $5 \mathrm{~mL}$ of sterile PBS, massaging and opening the peritoneum, and drawing back of the fluid with a Pasteur pipette $(\sim 5 \mathrm{~mL})$. Macrophages were collected by centrifugation (290xg, $4{ }^{\circ} \mathrm{C}$ for $5 \mathrm{~min}$ ), the pellet was washed, and then resuspended in PBS after counting in a Neubauer chamber by optical microscopy, using a Trypan blue solution (1\%). Adhesion assay and measurement of phagocytic capacity, lysosomal volume, superoxide anion production, and hydrogen peroxide production were performed using macrophage aliquots obtained in this manner.

\section{Adhesion assay}

Aliquots $(0.1 \mathrm{~mL})$ of macrophage suspension $\left(5 \times 10^{6}\right.$ cells $\left./ \mathrm{mL}\right)$ were added to the wells of a 96 -well flat- bottomed tissue culture plate and left to adhere for $1 \mathrm{~h}$ under controlled temperature $\left(37^{\circ} \mathrm{C}\right)$. After washing with PBS, $0.15 \mathrm{~mL}$ of $50 \%$ methanol was added to each well, and incubated for $10 \mathrm{~min}$ at room temperature. The supernatant was discarded, and $0.1 \mathrm{~mL}$ of $0.2 \%$ Giemsa solution was added. After incubating at room temperature for $40 \mathrm{~min}$, washing with distilled water, and incubating with $0.2 \mathrm{~mL}$ of $50 \%$ methanol at room temperature (Rosen, Gordon, 1987), the absorbance was measured at $550 \mathrm{~nm}$ (Microplate Reader 680; Biorad $\left.^{\circledR}\right)$. The mean of adhesion absorbance values of each group (C, 100 and 200) was used to normalize data for phagocytic capacity, lysosomal volume and ROS production assays (normalized value $=$ absorbance value of group $\mathrm{x} /$ mean of adhesion absorbance of group $\mathrm{x}$ ). This normalization was done to adapt results to the actual number of adherent cells on the plate.

\section{Phagocytic capacity}

Aliquots $(0.1 \mathrm{~mL})$ of macrophage suspension $\left(2 \times 10^{6}\right.$ cells $\left./ \mathrm{mL}\right)$ were added to the wells of a $96-$ well flat-bottomed tissue culture plate and left to adhere for $1 \mathrm{~h}$ under controlled temperature $\left(37^{\circ} \mathrm{C}\right)$. Then, $10 \mu \mathrm{L}$ of neutral red-stained zymosan $\left(1 \times 10^{8}\right.$ particles $\left./ \mathrm{mL}\right)$ were added to each well. After incubation for $30 \mathrm{~min}$ at $37^{\circ} \mathrm{C}$, the cells were then fixed with Baker's formol-calcium ( $4 \%$ formaldehyde, $2 \%$ sodium chloride, and $1 \%$ calcium acetate), $0.1 \mathrm{~mL} /$ well, for $30 \mathrm{~min}$. The cells were washed two times and centrifuged, and then, $0.1 \mathrm{~mL}$ of acidified alcohol (10\% acetic acid, $40 \%$ ethanol in distilled water) was added to each well (Bonatto et al., 2004). After $30 \mathrm{~min}$ at $37^{\circ} \mathrm{C}$, the absorbance was measured at $550 \mathrm{~nm}$ using the microplate reader.

\section{Lysosomal volume}

Lysosomal volume was measured using the method described by Pipe, Coles and Farley (1995). A macrophage suspension $\left(0.1 \mathrm{~mL}, 1 \times 10^{6}\right.$ cells $\left./ \mathrm{mL}\right)$ was incubated for $1 \mathrm{~h}$ at $37^{\circ} \mathrm{C}$, and then, $0.02 \mathrm{~mL}$ of $2 \%$ neutral red solution in PBS was added, and the samples were incubated for $30 \mathrm{~min}$ at $37^{\circ} \mathrm{C}$. The cells were washed twice with PBS and centrifuged. Neutral red was solubilized with $0.1 \mathrm{~mL}$ of the extraction solution ( $1 \%$ acetic acid in 50\% ethanol) (Bonatto et al., 2004). After $30 \mathrm{~min}$ of incubation at $37^{\circ} \mathrm{C}$, the absorbance was measured at $550 \mathrm{~nm}$ using the microplate reader.

\section{Superoxide anion production}

Superoxide production was estimated by the NBT 
reduction assay (Madhavi, Das, 1994). Macrophages $(0.1 \mathrm{~mL})$ suspended in PBS $\left(2 \times 10^{6}\right.$ cells $\left./ \mathrm{mL}\right)$ were incubated for $1 \mathrm{~h}$ at $37^{\circ} \mathrm{C}$ in the presence of $0.01 \mathrm{~mL}$ of $10 \mu \mathrm{M}$ phorbol myristate acetate (PMA). Subsequently, $0.1 \mathrm{~mL}$ of NBT solution $(0.25 \%)$ was added and the samples were incubated at $37{ }^{\circ} \mathrm{C}$ for $30 \mathrm{~min}$. After centrifugation, cells were fixed with $0.1 \mathrm{~mL}$ of $50 \%$ methanol. To assess the amount of superoxide anion production by the cells, the formazan resulting from NBT reduction was solubilized with $0.12 \mathrm{~mL}$ of $2 \mathrm{M}$ potassium hydroxide $(\mathrm{KOH})$ and $0.14 \mathrm{~mL}$ of DMSO. After 30 min of incubation, the absorbance was measured at $550 \mathrm{~nm}$ using the microplate reader.

\section{Hydrogen peroxide production}

Hydrogen peroxide production by macrophages was measured as described by Pick and Mizel (1981). This assay is based on horseradish peroxidase-dependent conversion of phenol red into a colored compound by $\mathrm{H}_{2} \mathrm{O}_{2}$. Macrophages $\left(0.1 \mathrm{~mL}, 2 \times 10^{6}\right.$ cells $\left./ \mathrm{mL}\right)$ were incubated at $37^{\circ} \mathrm{C}$ for $1 \mathrm{~h}$ and $10 \mu \mathrm{M}$ PMA $(0.01 \mathrm{~mL})$ was added to all the wells. Cells were then incubated in the presence of $0.1 \mathrm{~mL}$ of phenol red solution ( $5 \mathrm{mM}$ glucose, $0.56 \mathrm{mM}$ phenol red, and $8.5 \mathrm{U} / \mathrm{mL}$ horseradish peroxidase) in the dark for $1 \mathrm{~h}$ at $37^{\circ} \mathrm{C}$. The reaction was stopped by adding $0.01 \mathrm{~mL}$ of $1 \mathrm{M} \mathrm{NaOH}$, and the absorbance was measured at $655 \mathrm{~nm}$ using the microplate reader.

\section{Statistical analysis}

Data are presented as mean \pm standard error of the mean (SEM). Statistical analysis was performed by one way ANOVA followed by Tukey's post-hoc test. A $P$ value of $<0.05$ was considered statistically significant.

\section{RESULTS}

\section{Phytochemical analysis}

Phytochemical analysis by TLC suggested the presence of epicatechin in SAE (Figure 1A), and stigmasterol, lupeol and $\alpha$ and $\beta$-amyrin in the $\mathrm{SCHCl}_{3}$ (Figure 1B). The other compounds investigated were not found.

\section{Anti-inflammatory and analgesic effects}

Pretreatment of animals with CLD reduced carrageenan-induced edema formation by $36.8 \%$ and $50.2 \%$ at the 100 and $300 \mathrm{mg} / \mathrm{kg}$, respectively (Table I, $\mathrm{p}<0.05$ ). The higher dose of CLD reduced
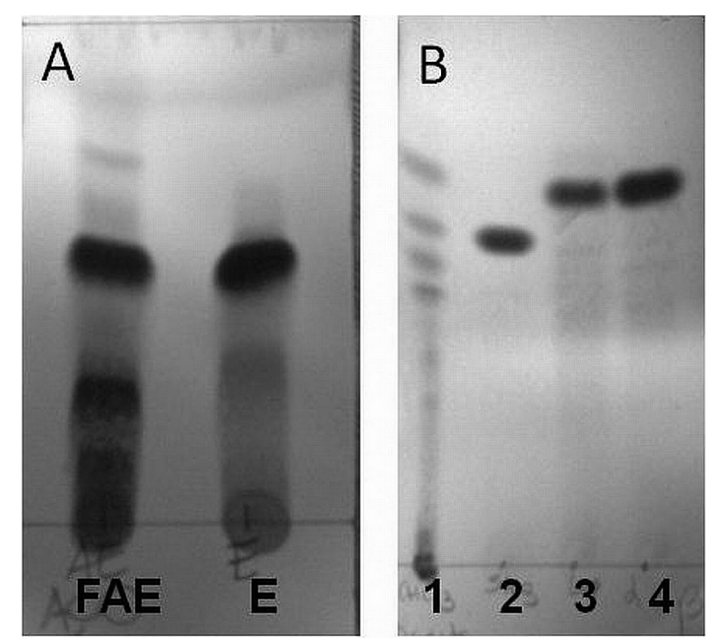

FIGURE 1 - Chromatographic profile of $L$. divaricata. Panel A: ethyl acetate fraction (SAE) and E, epicatechin. Panel B: chloroform fraction $\left(\mathrm{SCHCl}_{3}\right)$ (1), stigmasterol (2), lupeol (3) and $\alpha, \beta$-amyrin (4).

writhing by $64.4 \%$ (Table II, $\mathrm{p}<0.05$ ). Moreover, CLD significantly reduced the second phase of formalin reactivity (inflammatory phase) by $81.2 \%$ and $91.6 \%$ at 100 and $300 \mathrm{mg} / \mathrm{kg}$, respectively (Table II, $\mathrm{p}<0.05$ ). Capsaicin reactivity was also reduced; the time spent on painful activities was reduced by $63.9 \%$ in animals that received the higher dose of CLD (Table II).

\section{Adhesion capacity}

Animals that received $200 \mathrm{mg} / \mathrm{kg}$ of CLD (Group 200) significantly reduced macrophage adhesion compared to both the Control Group and Group 100 $(\sim 55 \%, \mathrm{p}<0.05)$. Group 100 showed similar adhesion capacity to the Control Group ( $\mathrm{p}>0.05$ ) (Figure 2).

\section{Phagocytic capacity}

Macrophages from Group 200 showed 3-fold increased phagocytic capacity than the Control Group $(\mathrm{p}<0.001)$ and Group $100(\mathrm{p}<0.001)$. There was no significant difference between the Control Group and Group $100(\mathrm{p}>0.05)$ (Figure 3).

\section{Lysosomal volume}

Neutral red uptake by the macrophages in Group 200 was $\sim 50 \%$ greater than that observed to the Control Group ( $p<0.001$ ), which was in contrast to the macrophages from Group 100, which showed a reduction of uptake capacity by $\sim 20 \%$. Group 200 presented $\sim 90 \%$ higher uptake capacity than Group 100 ( $\mathrm{p}<0.001$, Figure 4). 
TABLE I - Anti-inflammatory effect of crude extract of $L$. divaricata (CLD) on the paw edema induced by carrageenan test in mice

\begin{tabular}{|c|c|c|c|c|c|c|}
\hline \multirow[t]{2}{*}{ Groups } & \multirow[t]{2}{*}{ Dose $\mathrm{mg} / \mathrm{kg}$} & \multicolumn{4}{|c|}{$\begin{array}{c}\text { Paw edema induced by carrageenan }(300 \mu \mathrm{g} / \mathrm{paw}) \text { measured with } \\
\text { plethysmometer at different time points }\end{array}$} & \multirow{2}{*}{$\begin{array}{c}\text { Edema } \\
\text { inhibition (\%) }\end{array}$} \\
\hline & & $30 \mathrm{~min}$ & $60 \mathrm{~min}$ & $120 \min$ & $240 \mathrm{~min}$ & \\
\hline Control & distilled water & $32.5 \pm 6.1$ & $62.5 \pm 6.3$ & $112.5 \pm 13.1$ & $120.0 \pm 15.8$ & 0.0 \\
\hline \multirow{4}{*}{ Crude Extract } & 10 & $33.3 \pm 6.7$ & $46.6 \pm 4.2$ & $71.6 \pm 7.3$ & $96.6 \pm 6.7$ & 27.3 \\
\hline & 30 & $31.6 \pm 8.7$ & $43.3 \pm 5.5$ & $80.0 \pm 10.6$ & $106.6 \pm 8.0$ & 21.8 \\
\hline & 100 & $18.0 \pm 4.8$ & $34.0 \pm 8.1^{\mathrm{a}}$ & $62.0 \pm 10.6^{\mathrm{a}}$ & $94.0 \pm 7.5^{\mathrm{a}}$ & 36.8 \\
\hline & 300 & $4.0 \pm 2.4^{\mathrm{a}}$ & $24.0 \pm 7.4^{\mathrm{a}}$ & $60.0 \pm 13.8^{\mathrm{a}}$ & $64.0 \pm 8.1^{\mathrm{a}}$ & 50.2 \\
\hline
\end{tabular}

Each group represents the mean for 6 to 10 animals. Significantly different from control group: ${ }^{\text {a }} p<0.05$. Results are presented as mean \pm EPM values of the difference in volume $(\mathrm{mL})$ between the carrageenan- and saline-treated paws. The edema inhibition was determined by calculating the area under curve.

TABLE II - Analgesic effect of crude extract of $L$. divaricata (CLD) on the writhing test, paw formalin test and paw capsaicin test in mice

\begin{tabular}{|c|c|c|c|c|c|c|}
\hline \multirow{2}{*}{ Models } & & \multirow{2}{*}{ Control } & \multicolumn{4}{|c|}{ Dose of CLD (mg/kg) } \\
\hline & & & 10 & 30 & 100 & 300 \\
\hline Writhing test & number of writhings & $35.4 \pm 4.1$ & $26.0 \pm 3.4$ & $26.6 \pm 1.6$ & $25.0 \pm 4.1$ & $12.6 \pm 4.4^{\mathrm{a}}$ \\
\hline \multirow[t]{2}{*}{ Paw formalin test } & $1^{\text {st }}$ fase (seconds) & $57.0 \pm 7.7$ & $62.3 \pm 7.3$ & $41.3 \pm 3.1$ & $51.8 \pm 14.5$ & $50.6 \pm 11.2$ \\
\hline & $2^{\text {nd }}$ fase (seconds) & $76.0 \pm 16.4$ & $51.3 \pm 13.3$ & $37.8 \pm 14.1$ & $14.3 \pm 8.2^{\mathrm{a}}$ & $6.4 \pm 4.0^{\mathrm{a}}$ \\
\hline Paw capsaicin test & Reactivity (seconds) & $26.6 \pm 3.0$ & $30.3 \pm 4.6$ & $27.0 \pm 2.2$ & $9.6 \pm 2.1^{\mathrm{a}}$ & n.d. \\
\hline
\end{tabular}

Each group represents the mean \pm SEM for 6 to 10 animals. Significantly different from control group: ${ }^{a} p<0.05$. n.d., not determined. The time in seconds indicates time spent licking, flicking, and biting the injected paw.

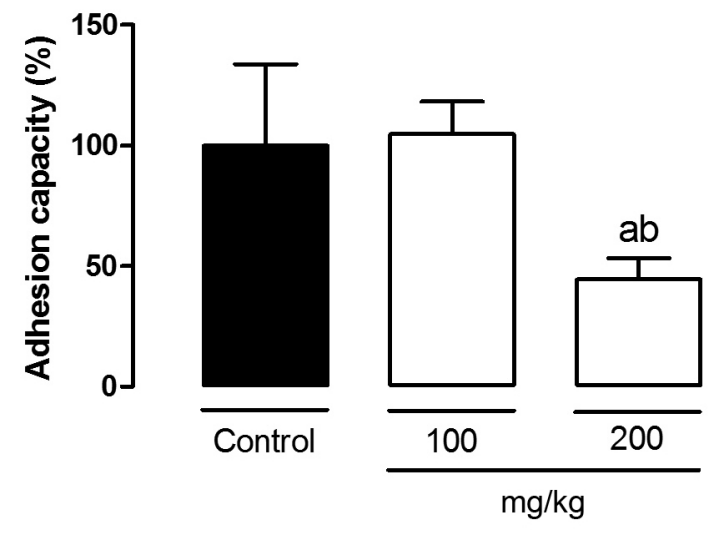

FIGURE 2 - Adhesion capacity of resident macrophages from mice fed regular chow (Control Group), treated with $100 \mathrm{mg} / \mathrm{kg}$ b.w. of CLD (Group 100), and $200 \mathrm{mg} / \mathrm{kg}$ b.w. (Group 200). ${ }^{a}$ $\mathrm{p}<0.05$ compared to Control. ${ }^{b} \mathrm{p}<0.05$ compared to Group 100 . Results are presented as \% relative to Control.

\section{Reactive oxygen species (ROS) production}

Superoxide anion (Figure 5) and hydrogen peroxide (Figure 6 ) production was $\sim 90 \%$ greater in the macrophages from Group 200 than those from the Control

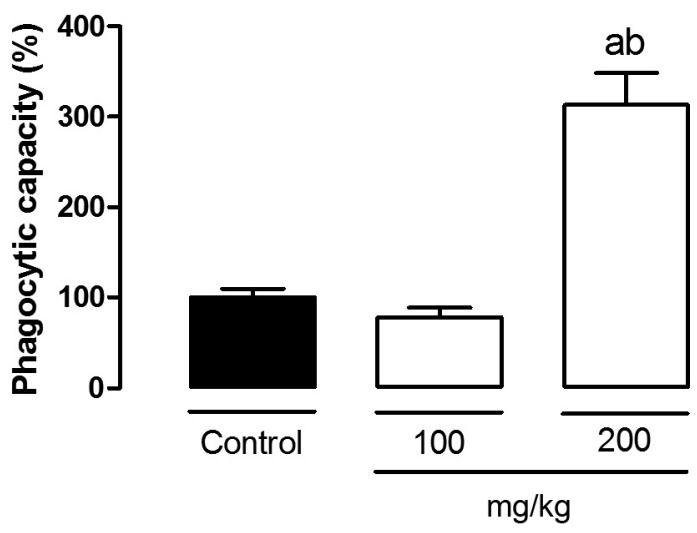

FIGURE 3 - Phagocytic capacity of resident macrophages from mice fed regular chow (Control Group), treated with $100 \mathrm{mg} / \mathrm{kg}$ b.w. of CLD (Group 100), and $200 \mathrm{mg} / \mathrm{kg} \mathrm{b.w}$. (Group 200). ${ }^{a} \mathrm{p}<0.001$ compared to Control. ${ }^{b} \mathrm{p}<0.001$ compared to Group 100. Results are presented as \% relative to Control.

Group ( $<<0.001$ ). The macrophages from Group 100 produced half the concentration of ROS compared to that of Group $200(p<0.001)$. No statistical difference was observed between the Control Group and Group 100. 


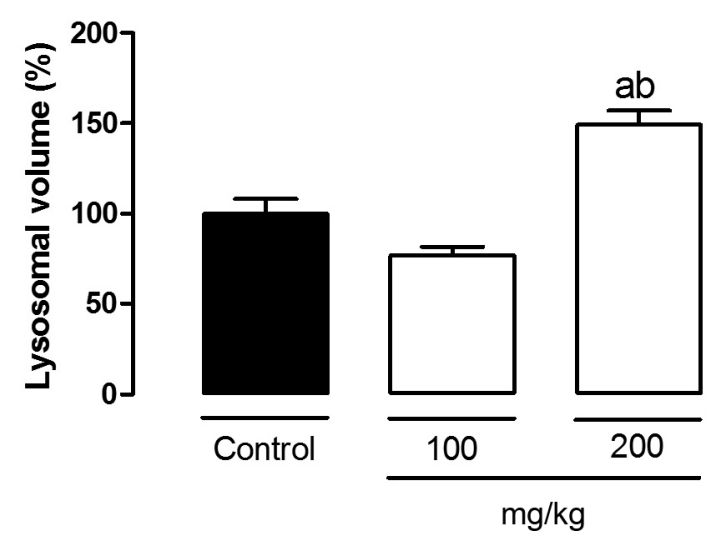

FIGURE 4 - Lysosomal volume of resident macrophages from mice fed regular chow (Control Group), treated with $100 \mathrm{mg} / \mathrm{kg}$ b.w. of CLD (Group 100), and $200 \mathrm{mg} / \mathrm{kg} \mathrm{b.w.}$ (Group 200). ${ }^{a} \mathrm{p}<0.001$ compared to Control. ${ }^{b} \mathrm{p}<0.001$ compared to 100 . Results are presented as $\%$ relative to control.

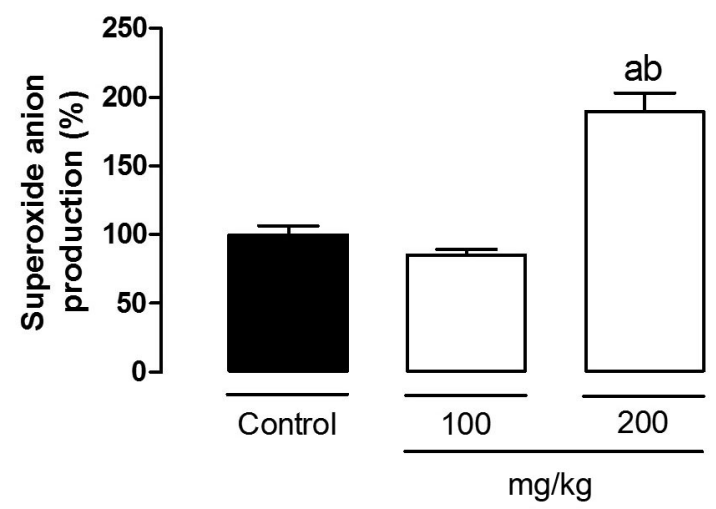

FIGURE 5 - Superoxide anion production of resident macrophages from mice fed regular chow (Control Group), treated with $100 \mathrm{mg} / \mathrm{kg} \mathrm{b.w.} \mathrm{of} \mathrm{CLD} \mathrm{(Group} \mathrm{100),} \mathrm{and}$ $200 \mathrm{mg} / \mathrm{kg}$ b.w. (Group 200). ${ }^{a} \mathrm{p}<0.001$ compared to Control. ${ }^{b}$ $\mathrm{p}<0.001$ compared to 100 . Results are presented as $\%$ relative to control.

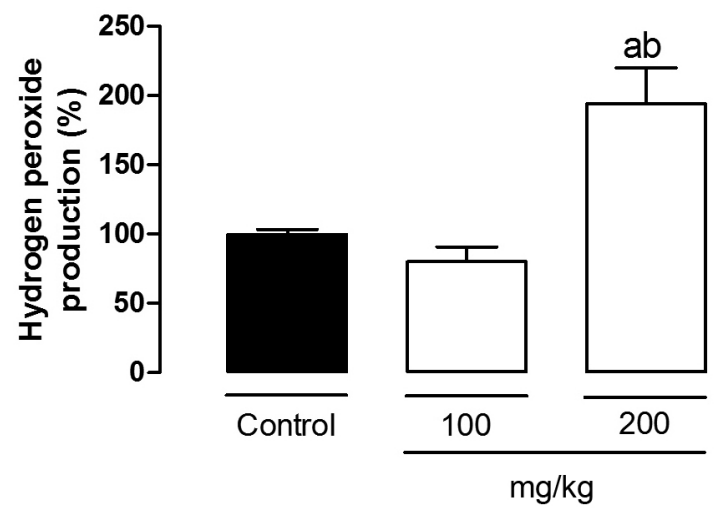

FIGURE 6 - Hydrogen peroxide production of resident macrophages from mice fed regular chow (Control Group), treated with $100 \mathrm{mg} / \mathrm{kg} \mathrm{b.w.} \mathrm{of} \mathrm{CLD} \mathrm{(Group} \mathrm{100),} \mathrm{and}$ $200 \mathrm{mg} / \mathrm{kg}$ b.w. (Group 200). ${ }^{a} \mathrm{p}<0.001$ compared to Control. ${ }^{b}$ $\mathrm{p}<0.001$ compared to 100 . Results are presented as $\%$ relative to control.

\section{DISCUSSION}

Bioactive compounds found in medicinal plants may present anti-inflammatory and analgesic capacities, in addition to immunomodulation properties. Indeed, many compounds isolated from plant extracts have demonstrated anti-inflammatory properties as well as immunostimulatory activities (da Silva, Parente, 2001; Biella et al., 2008; Halder et al., 2009). The current study characterizes the biological activity of $L$. divaricata bark for the first time, specifically showing that CLD reduced inflammation in all assays performed and that it stimulated macrophage activity.

Thin layer chromatography (Figure 1) revealed the presence of epicatechin in the SAE, and stigmasterol, lupeol and $\alpha$ and $\beta$-amyrin in the $\mathrm{SCHCl}_{3}$. Whereas some flavonoids and triterpenes exhibit immunomodulatory and anti-inflammatory activities (Saleem, 2009; Sabeva et al., 2011; Ahmad et al., 2013; Rosenblat, Volkova, Aviram, 2013), it is possible that they may be partly responsible for the activities found in the present study.

Carrageenan-induced paw edema is a wellcharacterized experimental model of inflammation, and it has been widely used to investigate the efficacy of natural compounds (Nardi et al., 2003; Wang et al., 2013). The acute inflammatory reaction elicited by carrageenan is characterized by sequential liberation of inflammatory mediators, promoting marked accumulation of exudate and intense migration of polymorphonuclear leukocytes in the affected paw (Morris, 2003). In the present study, we clearly show the anti-inflammatory properties of CLD, as demonstrated by a dose-dependent reduction in paw edema in mice (Table I). This effect was evident $30 \mathrm{~min}$ after the oral administration of CLD, and was maintained throughout the evaluation period.

The writhing test is an experimental model used to screen investigational drugs for analgesic activity. This is evaluated by the irritation caused by the i.p. injection of acetic acid, which causes the release of mediators such as bradykinin, prostaglandins, histamine, and 5-hydroxytryptamine (Whittle, 1964). Different of writhing test, in formalin test is possible to identify two phases of nociception. The first phase is characterized by direct activation of primary afferent fibers, followed by the second phase, which is characterized by the release of several inflammatory mediators in the immediate area of formalin injection (Hunskaar, Hole, 1987; Corrêa, Calixto, 1993; Choi, Lee, Suh, 2001). The CLD effectively reduced writhing behavior that suggests a level of pain in animals (Table II). This reduction in pain by CLD is further supported by the reduction in pain, as demonstrated in the 
second phase of formalin test for CLD-treated animals (Table II). The lack of effect of CLD in the first phase of the formalin test supports our hypothesis that antiinflammatory substances are responsible for the analgesic effect of CLD, rather than a direct excitation of the primary afferents.

Capsaicin is known to directly activate the vanilloid receptor (TRPV-1) in the primary afferent fibers, which transmits the nociceptive stimulus to the central nervous system, promoting the release of pro-inflammatory neuropeptides such as substance $\mathrm{P}$, neurokinins, nitric oxide, and prostaglandins. These substances are responsible for producing the sensation of pain and inflammatory process (Holzer, 1991; Wu et al., 1998; Palazzo, Rossi, Malone, 2008). The data on formalin test paired with the reduction in capsaicin-induced pain behavior suggests that CLD activity is due to the modulation of inflammatory mediators. Together with the reduction in edema in the carrageenan model, these data suggest that CLD contains anti-inflammatory substances, which act to reduce the sensation of pain by reducing inflammatory excitation of nociceptors in the primary afferent fibers.

Indigenous populations who use crude extract of $L$. divaricata to treat various conditions prepare infusions of the barks that are often administered orally. To simulate the effects of oral intake and evaluate the potential immunomodulatory activity of CLD, we orally administered CLD to animals for 15 days. According to Gertsch, Viveros-Paredes and Taylor (2011), the activity of the immune system can only unambiguously be evaluated in vivo, and the most ethnopharmacologically relevant way to test plant products is by oral administration. Here, we show that oral administration of a minimum of 200 $\mathrm{mg} / \mathrm{kg}$ CLD produced an overall stimulatory effect on the peritoneal macrophages from mice.

The adhesion capacity of the macrophages from Group 200 was reduced by $\sim 50 \%$ in comparison to those from both the Control Group and Group 100 (Figure 2). Modifications in the adhesion capacity of cells can be derived from changes in either the membrane fluidity (Calder et al., 1990; Noudeh et al., 2010) or in the distribution of adhesion molecules within the plasma membrane (KyungSeop et al., 2000; Kim et al., 2011). For example, there are reports showing that polyphenols and tannins contained in plant extracts are able to modify the properties of the plasma membrane, thereby affecting adhesion capacity (Cyboran, Oszmianski, Lkeszczynska, 2012; Olchowik et al., 2012). Interestingly, the phagocytic capacity observed in Group 200 was 3 -fold greater than that observed for Control Group $(\mathrm{p}<0.001)$ (Figure 3 ). This measurement was normalized by adhesion capacity, and although the adhesion capacity of the cells in Group 200 was $50 \%$ lower than that observed for the Control Group, the phagocytic capacity of adherent cells was still 3-fold greater. Together, these data indicate that the substances present in the barks of $L$. divaricata are able to stimulate a significant macrophage-mediated response, contributing to the body of evidence demonstrating that plant components influence immunomodulation by altering the phagocytic capacity of macrophages (Bin-Hafeez et al., 2003; Lee et al., 2007; Cruz et al., 2007) and other phagocytic cells (Nudo, Catap, 2011). However, a dose of $100 \mathrm{mg} / \mathrm{kg}$ did not elicit an impact on the adhesion and phagocytic capacity of isolated macrophages, suggesting an insufficient concentration of bioactive molecules to provide immunomodulation. Notwithstanding the lack of response in Group 100, the results obtained in the current study, particularly in relation to phagocytosis modulation, suggest that CLD is able to strongly stimulate the innate immune system at sufficient concentrations.

Cellular digestion of agents contained in phagosomes is controlled by fusion to hydrolase-containing lysosomal vesicles. Neutral red uptake by macrophages in Group 200 was greater than that observed in Group 100 and the Control Group (Figure 4). This supports the dose-dependent response observed in phagocytic capacity (Figure 3), indicating that the cells were able to both phagocytose the cationic dye neutral red and process it. However, the lysosomal volume of Group 200 did not show a proportional increase in neutral red uptake with respect to phagocytic capacity. This mismatch between phagocytosis and dye uptake has also been observed by other research groups (Bonatto et al., 2004). Swanson and Baer (1995) report that several events enable fusion between the lysosomal vacuolar membrane and phagosomes, which together form a phagolysosome. The rate of phagosome-lysosome fusion can vary dramatically depending on the nature of the encapsulated particles, suggesting that not all particles phagocytized stimulate a large change in lysosomal volume. This may partly explain the disparity between the results obtained for phagocytic capacity (Figure 3 ) and lysosomal volume (Figure 4) in Group 200.

Resting macrophages consume little oxygen, although activation by an appropriate stimulus leads to increased production of reactive oxygen species (ROS). ROS are produced by macrophages (superoxide anions and hydrogen peroxide) by a non-mitochondrial respiratory burst, which greatly increases consumption of oxygen and conversion to superoxide anions (Babior, 1984). The nicotinamide adenine dinucleotide phosphateoxidase (NADPH oxidase) enzyme that resides in the plasma membrane of phagocytes is responsible for this 
conversion, and it is activated by phagocytosis as well as by compounds such as PMA via activation of kinase C proteins (Lunardi, Lima, 2006). Superoxide anions and hydrogen peroxide that are immediate products of this respiratory burst lead to the generation of hypochlorite and chloramines, which are potent microbicidal oxidized halogens, in addition to hydroxyl radicals, an oxidizing radical that can damage all types of macromolecules (Babior, 1984). Our results show an increase in the concentrations of superoxide anion and hydrogen peroxide produced by the activated macrophages from Group 200 in comparison to those from Control Group (Figure 5 and Figure 6). These data are consistent with the increased phagocytic capacity of the macrophages from Group 200 animals. In these experiments, the cells of all groups were treated with PMA, but a greater concentration of superoxide anions and hydrogen peroxides were observed in Group 200 compared to Group C, suggesting that the crude extract at $200 \mathrm{mg} / \mathrm{kg}$ was able to stimulate the production of these ROS by macrophages. Studying the molecular mechanisms by which the compounds from CLD stimulate ROS production in macrophages was not the aim of this study, but we found that the crude extracts from medicinal plants are able to interact directly on the NADPH oxidase enzyme (Mahomoodally et al., 2012), suggesting that this action of the extract on this enzyme cannot be ruled out. Physiologically, the activation of phagocytic NADPH oxidase can be induced by microbial products such as bacterial lipopolysaccharide, by lipoproteins, or by cytokines such as interferon- $\gamma$, interleukin-1 $\beta$, or interleukin-8 (Bonizzi et al., 2000). In addition to exerting an important role as microbicidal agents, superoxides and related ROS contribute to signal transduction via various membrane receptors, and thus, to overall immunological function (Drogë, 2002).

Taken together, these results indicate that the CLD contains substances with both anti-inflammatory and analgesic effects, as well as immunomodulatory bioactive compounds capable of stimulating macrophage activity. These findings support the empirical use of this plant to combat different types of inflammatory diseases and infections. Further studies are necessary to elucidate the chemical compounds within CLD that contribute to these properties, and to evaluate the therapeutic effects exerted by these compounds on adaptive immune cells and their products.

\section{ACKNOWLEDGEMENTS}

We thank to FAPESC, CNPq and UNOESC for financial support.

\section{REFERENCES}

AHMAD, A.; GUPTA, G.; AFZAL, M.; KAZMI, I.; ANWAR, F. Antiulcer and antioxidant activities of a new steroid from Morus alba. Life Sci., v.92, p.202-210, 2013.

AREEJ, M.; ASSAF, A.M.; HADDADIN, R.N.; ALDOURI, N.A.; ALABBASSI, R.; MASHALLAH, S.; MOHAMMAD, M.; BUSTANJI, Y. Anti-cancer, antiinflammatory and anti-microbial activities of plant extracts used against hematological tumors in traditional medicine of Jordan. J. Ethnopharmacol., v.145, p.728-736, 2013.

BENTO, A.F.; MARCON, R.; CLAUDINO, R.F.; CALIXTO, J.B. Preventive and therapeutic oral administration of the pentacyclic triterpene $\alpha, \beta$-amyrin ameliorates dextran sulphate sodium-induced colitis in mice: The relevance of cannabinoid system. Mol. Immunol., v.54, p.482-492, 2013.

BABIOR, B.M. The respiratory burst of phagocytes. J. Clin. Invest., v.73, p.599-601, 1984.

BIELLA, C.A.; SALVADOR, M.J.; DIAS, D.A.; DIASBARUFF, M.; PEREIRA-CROTT, L.S. Evaluation of immunomodulatory and anti-inflammatory effects and phytochemical screening of Alternanthera tenella Colla (Amaranthaceae) aqueous extract. Mem. Inst. Oswaldo Cruz., v.103, p.569-577, 2008.

BIN-HAFEEZ, B.; HAQUE, R.; PARVEZ, S.; PANDEY, S.; SAYEED, I.; RAISUDDIN, S. Immunomodulatory effects of fenugreek (Trigonella foenum graecum L.) extract in mice. Int. Immunopharmacol., v.3, p.257-265, 2003.

BONATTO, S.J.R.; FOLADOR, A.; AIKAWA, J.; YAMAZAKI, R.K.; PIZATTO, N.; OLIVEIRA, H.H.P.; VECCHI, R.; CALDER, P.C.; FERNANDES, L.C. Lifelong exposure to dietary fish oil alters macrophage responses in Walker 256 tumor-bearing rats. Cell. Immunol., v.231, p.56-62, 2004.

BONIZZI, G.; PIETTE, J.; MERVILLE, M.P.; BOURS, V. Cell type-specific role for reactive oxygen species in nuclear factor $\mathrm{kB}$ activation by interleukin-1. Biochem. Pharmacol., v.59, p.7-11, 2000.

CALDER, P.C.; BOND, J.A.; HARVEY, D.J.; GORDON, S.; NEWSHOLME, E.A. Uptake and incorporation of saturated and unsaturated fatty acids into macrophage lipids and their effect upon macrophage adhesion and phagocytosis. Biochem. J., v.269, p.807-814, 1990. 
CHOI, S.S.; LEE, J.K.; SUH, H.W. Antinociceptive profiles of aspirin and acetaminophen in formalin, substance $\mathrm{P}$ and glutamate pain models. Brain Res., v.921, p.233-239, 2001.

COELHO DE SOUZA, G.; HAAS, A.P.S.; VON POSER, G.L.; SCHAPOVAL, E.E.S.; ELISABETSKY, E. Ethnopharmacological studies of antimicrobial remedies in the South of Brazil. J. Ehtnopharmacol., v.90, p.135$143,2004$.

CORRÊA, C.R.; CALIXTO, J.B. Evidence for participation of $\mathrm{B} 1$ and $\mathrm{B} 2$ kinin receptors in formalin-induced nociceptive response in the mouse. Br. J. Pharmacol., v.110, p.193-198, 1993.

CRUZ, G.V.B.; PEREIRA, P.V.S.; PATRÍCIO, F.J.; COSTA, G.C.; SOUSA, S.M.; FRAZÃO, J.B.; ARAGÃO-FILHO, W.C.; MACIEL, M.C.G.; SILVA, L.A.; AMARAL, F.M.M.; BARROQUEIRO, E.S.B.; GUERRA, R.N.M.; NASCIMENTO, F.R.F. Increase of cellular recruitment, phagocytosis ability and nitric oxide production induced by hydroalcoholic extract from Chenopodium ambrosioides leaves. J. Etnopharmacol., v.111, p.148-154, 2007.

CYBORAN, S.; OSZMIANSKI, J.; KLESZCZYNSKA, H. Interaction between plant polyphenols and the erythrocytes membrane. Cell. Mol. Biol. Lett., v.17, p.77-88, 2012.

DA SILVA, B.P.; PARENTE, J.P. An anti-inflammatory and immunomodulatory polysaccharide from Orbignya phalerata. Fitoterapia., v.72, p.887-893, 2001.

DROGË, W. Free radicals in the physiological control of cell function. Physiol. Rev., v.82, p.47-95, 2002.

GERTSCH, J.; VIVEROS-PAREDES, J.M.; TAYLOR, P. Plant immunostimulants - scientific paradigm or myth? J. Ethnopharmacol., v.136, p.385-391, 2011.

HALDER, S.; BHARAL, N.; MEDIRATTA, P.K.; KAUR, I.; SHARMA, K.K. Anti-inflammatory, immunomodulatory and antinociceptive activity of Terminalia arjuna Roxb bark powder in mice and rats. Indian J. Exp. Biol., v.47, p.577-583, 2009.

HOLZER, P. Capsaicin: cellular targets mechanisms of action and selectivity for thin sensory neurons. Pharmacol. Rev., v.43, p.144-201, 1991.
HOSTETTMANN, K.; MARSTON, A.; HOSTETTMANN, M. Preparative chromatography techniques: applications in natural product isolation. 2.ed. Berlin: Springer, 1998. 244 p.

HUNSKAAR, S.; HOLE, K. The formalin test in mice: dissociation between inflammatory and non-inflammatory pain. Pain, v.30, p.103-114, 1987.

KALLUF, L.J.H. Fitoterapia funcional: dos princípios ativos à prescrição de fitoterápicos. São Paulo: VP Editora, 2008. $304 \mathrm{p}$.

KIM, Y.S.; JEON, J.H.; IM, J.; KANG, S.S.; CHOI, J.N.; JU, H.R.; YUN, C.H.; SON, C.G.; LEE, C.H.; HAN, S.H. Induction of intercellular adhesion molecule-1 by watersoluble components of Hericium erinaceum in human monocytes. J. Ethnopharmacol., v.133, p.874-880, 2011.

KOSTER, R., ANDERSON, M., DEBEER, E.J. Acetic acid for analgesic screening. Fed. Proc., v.18, p.418-420, 1959.

KYUNGSEOP, A.; JUNGHEE, K.; SEIRYANG, O.; SHIYONG, R.; HYEONGKYU, L. Inhibitory activity of stilbenes from medicinal plants on the expression of cell adhesion molecules on THP1 cells. Planta Med., v.66, p.641-644, 2000 .

LEE, Y.G.; BYEON, S.E.; KIM, J.Y.; LEE, J.Y.; RHEE, M.H.; HONG, S.; WU, J.C.; LEE, H.S.; KIM, M.J.; CHO, D.H.; CHO, J.Y. Immunomodulatory effect of Hibiscus cannabinus extract on macrophage functions. $J$. Etnopharmacol., v.113, p.62-71, 2007.

LICCIARDI, P.V.; UNDERWOOD, J.R. Plant-derived medicines: A novel class of immunological adjuvants. Int. Immunopharmacol., v.11, p.390-398, 2011.

LUNARDI, F.; LIMA, I.H.C.; ASSREUY, J. Comparative study of respiratory burst induced by phorbol ester and zymosan in human granulocytes. Clin. Biochem., v.39, p.78-85, 2006.

MADHAVI N.; DAS, V.N. Effects of n-3 and n-6 fatty acids on the survival of vincristine sensitive and resistent human carcinoma cells, in vitro. Cancer Lett., v.84, p.31-41, 1994.

MAHOMOODALLY, F.; MESAIK, A.; CHOUDHARY, M.I.; SUBRATTY, A.H.; GURIB-FAKIM, A. In vitro modulation of oxidative burst via release of reactive oxygen species from immune cells by extracts of selected tropical medicinal herbs and food plants. Asian Pac. J. Trop. Med., v.5, p.440447, 2012. 
MEHROTRA, S.; MISHRA, K.P.; MAURYA, R.; SRIMAL, R.C.; SINGH, V. Immunomodulation by ethanolic extract of Boerhaavia diffusa roots. Int. Immunopharmacol., v.2, p.987-996, 2002.

MORRIS, C.J. Carrageenan-induced paw edema in the rat and mouse. Methods Mol. Biol., v.225, p.115-121, 2003.

NAPOLITANO, D.R.; MINEO J.R.; SOUZA M.A.; PAULA, J.E.; ESPINDOLA, L.S.; ESPINDOLA, F.S. Down-modulation of nitric oxide production in murine macrophages treated with crude extracts from Brazilian Cerrado. J. Etnopharmacol., v.99, p.37-41, 2005.

NARDI, G.M.; FELIPPI, R.; DALBÓ, S.; SIQUEIRAJUNIOR, J.M.; ARRUDA, D.C.; DELLE MONACHE, F.; TIMBOLA, A.K.; PIZZOLATTI, M.G.; CKLESS, K.; RIBEIRO-DO-VALLE, R.M. Anti-inflammatory and antioxidant effects of Croton celtidifolius bark. Phytomedicine, v.10, p.176-184, 2003.

NOUDEH, G.D., SHARIFIFAR, F.; KHATIB, M.; BEHRAVAN, E.; AFZADI, M.A. Study of aqueous extract of three medicinal plants on cell membrane-permeabilizing and their surface properties. Afr. J. Biotechnol., v.9, p.110-116, 2010.

NUDO, L.P.; CATAP, E.S. Immunostimulatory effects of Uncaria perrottetii (A. Rich) Merr.(Rubiaceae) vinebark aqueous extract in Balb/C mice. J. Etnopharmacol., v.133, p.613-620, 2011.

OJEWOLE, J.A.O. Antinociceptive, anti-inflammatory and antidiabetic properties of Hypoxis hemerocallidea Fisch. \& C.A. Mey. (Hypoxidaceae) corm ['African Potato'] aqueous extract in mice and rats. J. Etnopharmacol., v.103, p.126-134, 2006.

OLCHOWIK, E.; LOTKOWSKI, K.; MAVLYANOV, S.; ABDULLAJANOVA, N.; IONOV, M.; BRYSZEWSKA, M.; ZAMARAEVA, M. Stabilization of erythrocytes against oxidative and hypotonic stress by tannins isolated from sumac leaves (Rhus typhina L.) and grape seeds (Vitis vinifera L.). Cell. Mol. Biol. Lett., v.17, p.333-348, 2012.

PALAZZO, E.; ROSSI, F.; MALONE, S. Role of TRPV1 receptors in descending modulation of pain. Mol. Cell. Endocrinol., v.286, p.79-83, 2008.
PETHO, G.; REEH, P.W. Sensory and signaling mechanisms of bradykinin, eicosanoids, platelet-activating factor, and nitric oxide in peripheral nociceptors. Physiol. Rev., v.92, p.1699-1775, 2012.

PICK, E.; MIZEL D. Rapid microassays for measurement of superoxide and hydrogen peroxide production by macrophages in culture using an automatic enzyme immunoassay reader. J. Immunol. Methods, v.46, p.211226, 1981.

PIPE, R.K.; COLES, J.A.; FARLEY, S.R. Assays for measuring imune response in the mussel Mytilus edulis. Tech. Fish Immunol., v.4, p.93-100, 1995.

ROSEN, H.; GORDON, S. Monoclonal antibody to the murine type 3 complement receptor inhibits adhesion of myelomonocytic cells in vitro and inflammatory cell recruitment in vivo. J. Exp. Med., v.166, p.1685-1701, 1987.

ROSENBLAT, M.; VOLKOVA, N.; AVIRAM, M. Pomegranate phytosterol ( $\beta$-sitosterol) and polyphenolic antioxidant (punicalagin) addition to statin, significantly protect against macrophage foam cells formation. Atherosclerosis, v.226, p.110-117, 2013.

SABEVA, N.S.; McPHAUL, C.M.; LI, X.; CORY, T.J.; FEOLA, D.J.; GRAF, G.A. Phytosterols differentially influence ABC transporter expression, chlolesterol efflux and inflammatory cytokine secretion in macrophage foam cells. J. Nutr. Biochem., v.22, p.777-783, 2011.

SAKURADA, T.; KATSUMATA, K.; TAN-NO, K.; SAKURADA, S.; KISARA, K. The capsaicin test in mice for evaluating tachykinin antagonists in the spinal cord. Neuropharmacology, v.3, p.1279-1285, 1992.

SIRIWATANAMETANON, N.; FIEBICH B.L.; EFFERTH, T.; PRIETO, J.M.; HEINRICH, M. Traditionally used Thai medicinal plants: In vitro anti-inflammatory, anticancer and antioxidant activities. J. Ethnopharmacol., v.130, p.196-207, 2010.

SALEEM, M. Lupeol, a novel anti-inflammatory and anti-cancer dietary triterpene. Cancer Lett., v.285, p.109-115, 2009.

SUFFREDINI, A.F.; FANTUZZI, G.; BADOLATO, R.; OPPNHEIM, J.J.; O'GRADY, N.P. New insights into the biology of the acute phaseresponse. J. Clin. Immunol., v.19, p.203-214, 1999. 
SWANSON, J.A.; BAER, S.C. Phagocytosis by zippers and triggers. Trends Cell. Biol., v.5. p.89-93, 1995.

TANAKA, J.C.A.; SILVA, C.C.; DIAS FILHO, B.P.; NAKAMURA, C.V.; CARVALHO, J.E.; FOGLIO, M.A. Chemical constituents of Luehea divaricata Mart. (TILIACEAE). Quím. Nova, v.28, p.834-837, 2005.

TANAKA, J.C.A.; VIDOTTI, G.J.; SILVA, C.C. A New Tormentic Acid Derivative from Luehea divaricata Mart. (Tiliaceae). J. Braz. Chem. Soc., v.14, p.475-478, 2003.

TIWARI, U.; RASTOGI, B.; SINGH, P.; SARAF, D.K.; VYAS, S.P. Immunomodulatory effects of aqueous extract of Tridax procumbens in experimental animals. J. Ethnopharmacol., v.92, p.113-119, 2004.

WANG, B.S.; HUANG, G.J.; LU, Y.H.; CHANG, L.W. Antiinflammatory effects of an aqueous extract of Welsh onion green leaves in mice. Food Chem., v.138, p.751-756, 2013.
WHITTLE, B.A. Release of a kinin by intraperitoneal injection of chemical agents in mice. Int. J. Neuropharmacol., v.3, p.369-378, 1964.

WU, J.; LIN, Q.; MCADOO, D.J.; WILLIS, W.D. Nitric oxide contributes to central sensitization following intradermal injection of capsaicin. NeuroReport, v.9, p.589-592, 1998.

ZACCHINO, S.; SANTECCHIA, C.; LÓPEZ, S.; GATTUSO, S.; MUÑOZ, J.D.; CRUÃNES, A.; VIVOT, E.; CRUÃNES, M.C.; SALINAS, A.; RUIZ, R.E.; RUIZ, S. In vitro antifungal evaluation and studies on mode of action of eight selected species from the Argentina flora. Phytomedicine, v.5, p.389-395, 1998.

Received for publication on $11^{\text {st }}$ September, 2013 Accepted for publication on $03^{\text {rd }}$ April 2014 